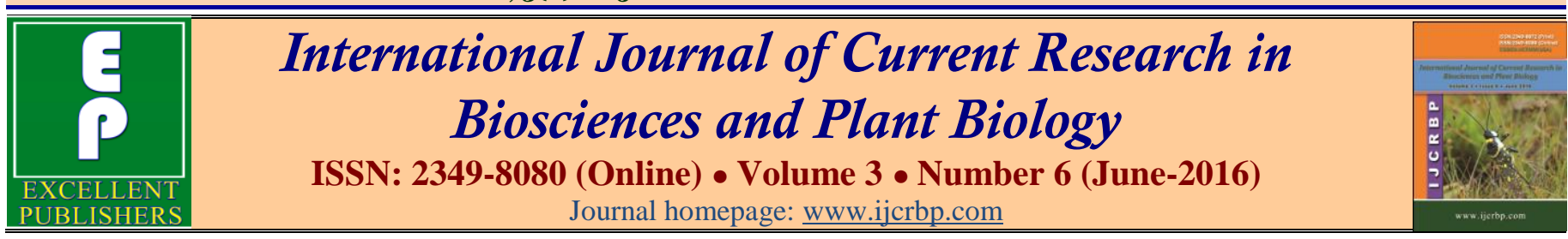

\title{
Effect of Long Term Fertilization on Content and Uptake of Macro Nutrients in Sorghum-Wheat Cropping Sequence - A Review
}

\author{
Mohana Rao Puli*, R. N. Katkhar, Jayalakshmi Mitnala and Burla Srihari Rao \\ Department of Soil Science and Agricultural Chemistry, Dr. Panjabrao Deshmukh Krishi Vidya Peeth, Akola, M.S., India \\ *Corresponding author.
}

\begin{abstract}
A b stract
Sorghum and wheat are the premier food grain crops of the peninsular central India and in particular of Maharashtra. There has been a phenomenal increase in its production after mid sixties with the introduction of high yielding varieties. Increase in production was achieved through increase in area as well as productivity. Inputs like improved seeds, irrigation, fertilizers etc. has given a boost to productivity. Continuous addition of chemical fertilizers poses problems like toxicity due to high amounts of salts as residues of fertilizer and deterioration of the physico-chemical properties. Organic manure ameliorates this problem as organic matter helps in increasing adsorptive power of soil for cations and anions particularly phosphate and nitrate. Long term manuring and fertilizer experiments conducted in India showed declining trend in productivity even with the application of NPK fertilizers under modern intensive farming. Neither organic source alone nor inorganic fertilizers can achieve sustainability in crop production under intensive agriculture, where nutrient turnover in soil-plant system is much higher. However, their combined use appeared promising in enhanced crop productivity besides improving soil fertility.
\end{abstract}

\section{Introduction}

\section{Content and uptake of macronutrients}

Tiwari et al. (1980) observed increase in the uptake of nutrients in grain and straw of rice with green manuring. The concentration of $\mathrm{N}, \mathrm{P}$ and $\mathrm{K}$ at tillering stage was significantly higher with the application of green manuring. Walia et al. (1980) reported that concentration and uptake of NPK by wheat was increased with $\mathrm{N}$ application. It was further noticed that about 73, 84 and 19 per cent of $\mathrm{N}, \mathrm{P}$ and $\mathrm{K}$ absorbed by the crop were accumulated in wheat grains.

Subbarao et al. (1982) recorded higher $\mathrm{N}$ removal by crops with $150 \%$ NPK, $100 \%$ NPK and 50\% NPK respectively. Application of both $\mathrm{N}$ and $\mathrm{NP}$ at the recommended rates enhanced $\mathrm{N}$ removal by 70 and 19 per cent respectively over control and $100 \% \mathrm{~N}$ similarly, slightly higher $(3.5 \%) \mathrm{N}$ uptake was recorded as $100 \%$ NPK over 100\% NP level. Mandal and Roy (1984) found higher $\mathrm{N}$ uptake with increasing NPK levels, and NPK combination enhanced $\mathrm{N}$ uptake over $\mathrm{N}$ and NP. More and Ghonshikar (1984) during working on sorghumwheat and green gram-wheat sequence observed an increase in the $\mathrm{N}$ uptake with increasing $\mathrm{N}$ levels.

Patil et al. (1984) reported that higher $\mathrm{N}$ levels applied to sorghum in Vertisol resulted in its higher uptake and application of NPK also increased in the uptake of P. Similarly higher $\mathrm{K}$ application up to $60 \mathrm{~kg} \mathrm{~K}_{2} \mathrm{O}$ per ha resulted in corresponding increased $\mathrm{K}$ uptake. Highest $\mathrm{N}$, $\mathrm{P}$ and $\mathrm{K}$ uptake were obtained with 150:60:60 kg NPK per ha. The combination N-120, K-60 recorded 
significantly higher $\mathrm{N}, \mathrm{P}$ and $\mathrm{K}$ uptake in sorghum grain over N-100, P-60 and K-60 dose. Indulkar and More (1985) found that $\mathrm{N}$ content in sorghum grain and fodder was increased with the increase in $\mathrm{N}$ levels continuously in sorghum-wheat sequence on a calcareous soil.

Naphade and Wankhade (1987) observed that there was significant increase in content of $\mathrm{N}$ and $\mathrm{P}$ in grain and straw of mung due to $\mathrm{S}$ application. The uptake of $\mathrm{N}$ in grain and straw increased significantly due to fertilization of $50 \mathrm{~kg} \mathrm{~S}$ per ha. Vageesh et al. (1987) observed increasing $\mathrm{N}$ uptake with increasing $\mathrm{N}$ and $\mathrm{P}$ levels in sorghum-wheat sequence in Vertisol. The highest $\mathrm{N}$ uptake was recorded at N-120, P-80 and K-40 combination

Zade (1991) reported that $\mathrm{N}$ and $\mathrm{P}$ content in wheat grains were significantly increased with the increasing $\mathrm{N}$ or P levels and prominently by NP combination in long term cropping sequence of sorghum-wheat. Bhandari et al. (1992) reported significant favourable effect of green manuring on uptake of $\mathrm{N}, \mathrm{P}$ and $\mathrm{K}$ increased with increase in NPK levels in rice-wheat cropping sequence. Naphade et al. (1993) reported that application of FYM with NPK increased the uptake greatly as compared to application of NPK alone by wheat crop. Combined application of $\mathrm{N}$ and $\mathrm{P}$ increased the uptake of $\mathrm{N}, \mathrm{P}$ and $\mathrm{K}$ by $26.4,28.1$ and 26.9 per cent over $\mathrm{N}$.

Tyagi and Bhardwaj (1994) revealed that FYM treated plots recorded the highest uptake of all the nutrients, indicating that the addition of FYM along with $100 \%$ NPK increased the uptake of nutrients to a greater extent in rice-wheat rotation. Dudhat et al. (1997) reported that application of FYM alone or in combination with chemical fertilizers significantly increased nutrient uptake by wheat. Kaushik and Sharma (1997) reported that the $\mathrm{N}$ concentration in grain and straw increased with $\mathrm{N}$ rate and application of $20 \mathrm{~kg} \mathrm{~S}^{-1}$ while total $\mathrm{N}$ uptake increased with increasing $\mathrm{N}$ and $\mathrm{S}$ rates.

Mali et al. (1997) observed that the application of FYM lowered the $\mathrm{P}$ content in sorghum crop, whereas, it showed a significant increase in wheat crop. Tiwari et al. (1998) studied the direct and residual effect of incorporation of green groundnut haulm with fertilizers on yield and nutrient uptake by wheat. They also noticed that the uptake of N, P, K, Ca, Mg, S, Zn, Fe and Mn by wheat was significantly increased due to increasing levels of $\mathrm{N}$ as 50 and $100 \mathrm{~kg} \mathrm{ha}^{-1}$ when incorporated in combination with $7.5 \mathrm{Mg} \mathrm{ha}{ }^{-1}$ groundnut haulm. Srinivasarao and Subbarao (1999) reported that the higher $\mathrm{K}$ uptake was recorded due to optimum $\mathrm{O}_{2}$ supply to crop which may be attributed to balanced fertilization under soybean-wheat sequence. The combined effect of $\mathrm{P}$ and FYM was more prominent in uptake by straw and total $\mathrm{K}$ uptake rather than their individual application.

Zbiec et al. (1999) noticed that $\mathrm{N}$ and other mineral content of grain and straw generally increased with increasing dose of NPK. Dixit and Gupta (2000) conducted field experiment on inceptisol during two consecutive kharif seasons of 1993 and 1994 at Kanpur and revealed that highest $\mathrm{N}$ content in grain (1.19 per cent) was recorded with N-120, P-60 and K-60 during first year and 1.21 per cent during second year. There was a slight increase in $\mathrm{N}$ content up to 1.24 per cent with every increase in $\mathrm{N}$ level.

Kundu et al. (2000) reported that $\mathrm{N}$ uptake increased with the level of applied $\mathrm{N}$ and it was significantly higher in the gypsum treated pots at all levels of $\mathrm{N}$ application. Depending up on the levels of applied $\mathrm{N}$, gypsum application increased $\mathrm{N}$ uptake by 23.9 to 38.9 per cent over no gypsum treatment. The significantly higher $\mathrm{N}$ uptake due to gypsum treatment could have contributed towards the relatively higher grain and straw yields.

Pandey et al. (2000) conducted an experiment during 2000 showed that NPK uptake was enhanced significantly with fertilizer dose $120+60 \mathrm{~kg} \mathrm{NPK} \mathrm{ha}^{-1}$. Reddy and Raqueeba (2000) found an increase in $\mathrm{S}$ uptake with advancing age of the crop under groundnutsoybean-wheat cropping system.

Randhava and Arora (2000) observed in a pot culture experiment that in the absence of added $\mathrm{S}$ in Typic Ustochrepts the total $\mathrm{P}$ uptake by wheat increased from $58.73 \mathrm{mg}$ in control pot to $89.12 \mathrm{mg}$ per pot at $50 \mathrm{mg} \mathrm{P}$ per $\mathrm{kg}$ and declined at $100 \mathrm{mg} \mathrm{P}$ per $\mathrm{kg}$ in Typic Ustipsamments, the decrease was from $32.35 \mathrm{mg}$ to $59.40 \mathrm{mg}$ per pot at $100 \mathrm{mg}$ P per kg. Rawat et al. (2000) Studied that the refinement of agro-techniques for improving productivity of wheat (Triticum aestivam) and absorved that use of recommended dose of fertilizers $\left(120 \mathrm{~kg} \mathrm{~N}+60 \mathrm{~kg} \mathrm{P}_{2} \mathrm{O}_{5}+60 \mathrm{~kg} \mathrm{~K}_{2} \mathrm{O} \mathrm{ha}^{-1}\right)$ to wheat significantly improve the $\mathrm{N}, \mathrm{P}$, and $\mathrm{K}$ uptake. They further stated that nutrient uptake was enhanced due to quick dissolution and availability of nutrients to crop.

Vats et al. (2001) observed that in addition to sustainable yield of grains, use of organic manure has significantly increased the availability of limiting nutrients in the soil and thus maintained the fertility of different soils. Barik 
and Goswami, (2003) conducted an experiment during 1999-2000 to study the effect of inorganic fertilizer on growth and productivity of wheat and noted that application of $100 \%$ RDF had significant improvement in $\mathrm{N}, \mathrm{P}$ and $\mathrm{K}$ uptake as compare to $75 \% \mathrm{RDF}$.

Nazikar and Adsule (2004) conducted an experiment on wheat uptake and they observed that application of 120 $\mathrm{kg} \mathrm{N}$ through urea increased NPK uptake in grain as well as straw of wheat. Pathak et al., 2005 reported that the nutrient uptake is dependable factor on the application of fertilizer, fertilizer dose will vary the nutrient uptake in wheat, application of $100 \%$ RDF resulted in significant increase in NPK uptake by wheat grain and straw. Singh et al. (2006) pointed out that application of $100 \% \mathrm{RDF}$ produced significantly higher NPK uptake by grain and straw.

Yaduvanshi and Swarup (2006) observed more distribution of water soluble and exchangeable potassium content of the top $(0-15 \mathrm{~cm})$ soil in the treatments received K fertilizer (159\% NPK, 100\% NPK and 100\% $\mathrm{NPK}+\mathrm{FYM}$ ) as compared to $100 \% \mathrm{~N}$ or $100 \% \mathrm{NP}$ treatments. Chander et al. (2007) observed that the incorporation of FYM resulted in to a significant and consistent increase in Ca uptake in cauliflower.

\section{Relationship of soil parameters and yield}

Hazara et al. (1980) revealed that combined application of wheat straw @ $8 \mathrm{t} \mathrm{ha}^{-1}$ and $\mathrm{N}$ fertilizers gave higher grain and straw yield than that of $\mathrm{N}$ fertilizer alone. Walia et al. (1980) noted that grain and straw yield of wheat was increased with the increasing $\mathrm{N}$ levels applied to loamy sand and sandy loam soils of Punjab.

Kulkarni et al. (1983) reported that application of 12 tonnes FYM with $90 \mathrm{~kg} \mathrm{~N} \mathrm{ha}^{-1}$ to kharif crop followed by $60 \mathrm{~kg} \mathrm{~N}^{-1}$ to the rabi crop could produce a satisfactory yield as comparable to $150 \mathrm{~kg} \mathrm{~N}, 60 \mathrm{~kg} \mathrm{P}_{2} \mathrm{O}_{5}$ and $60 \mathrm{~kg}$ $\mathrm{K}_{2} \mathrm{O}$ ha $^{-1}$ to kharif and $60 \mathrm{~kg} \mathrm{~N} \mathrm{ha}^{-1}$ to rabi crop. Kumar and Singh (1984) noticed the increased response of wheat to $\mathrm{N}$ application up to $120 \mathrm{~kg} \mathrm{~N}^{-1}$ with increased grain and straw yield. Patil et al. (1984) observed in a field trail on Vertisol, application of 150:60:60 kg NPK ha ${ }^{-1}$ significantly increased the grain and fodder yield of sorghum. Dhonde (1985) reported that the average grain yield of sorghum increased with increasing levels of $\mathrm{N}$. The application of $90 \mathrm{~kg} \mathrm{~N} \mathrm{ha}^{-1}$ produced the highest grain yield of $22.47 \mathrm{q} \mathrm{ha}^{-1}$ which was 68,33 and 13 per cent higher than the $0,30,60 \mathrm{~kg} \mathrm{~N}$ $\mathrm{ha}^{-1}$ respectively. Dhupta et al. (1986) found that sorghum hybrid CSH-5, SPV-245 and Aspuri gave average yield of 2.31, 1.92 and 1.52 tonnes grain and 7.41, 7.77 and 13.23 tonnes Stover per ha respectively. They further reported that increasing $\mathrm{N}$ levels from 0 to $90 \mathrm{~kg} \mathrm{ha}^{-1}$ increased grain yield from 6.28 to 11.88 tonnes ha- ${ }^{-1}$.

Sahrawat et al. (1998) reported that the fertilizer $\mathrm{P}$ increased grain and straw yield. $\mathrm{P}$ application also increased the nutrient harvest index for macro and micro nutrient elements in sorghum. Badanur et al. (1990) reported that the yield of rabi sorghum grain obtained due to application of $50 \mathrm{~kg} \mathrm{~N}$ and $25 \mathrm{~kg} \mathrm{P}_{2} \mathrm{O}_{5} \mathrm{ha}^{-1}$ was on par with incorporation of Leuceana leucocephala @ $5 \mathrm{t} \mathrm{ha}^{-1}$.

Bhosekar and Raikhedkar (1990) observed that the application of $80 \mathrm{~kg} \mathrm{~N}^{-1}$ gave significantly higher grain weight per ear head grain yield per ear head and grain yield as compared to its higher and lower $\mathrm{N}$ levels. They further reported that the application of $80 \mathrm{~kg} \mathrm{ha}^{-1}$ with FYM @ $6 \mathrm{t} \mathrm{ha}^{-1}$ significantly influenced grain weight per ear head, which resulted in highest grain yield of sorghum. Dhillon and Dhillon (1991) reported that the yield of groundnut and wheat obtained with the application of $40 \mathrm{~kg} \mathrm{P}_{2} \mathrm{O}_{5} \mathrm{ha}^{-1}$ in combination with crop residues were at par with that obtained by applying $60 \mathrm{~kg}$ $\mathrm{P}_{2} \mathrm{O}_{5} \mathrm{ha}^{-1}$ to wheat grown in rotation with groundnut.

Zade (1991) reported that in sorghum-wheat sequence the application of NPK fertilizers increased the grain and straw yield of both the crops. Raghuvanshi and Umat (1994) studied the possibility of N saving to the extent of at least 25 to 50 per cent by applying FYM or green crop. Residual effect of organics was pronounced leading to average grain yield of wheat for two years in the treatment receiving $50 \%$ of recommended dose through FYM and 50\% through chemical fertilizer and gave highest grain yield of wheat-sorghum in a sequence.

Naphade et al. (1995) reported that the grain yields of sorghum and wheat obtained due to application of $100 \%$ recommended dose of NPK through fertilizer plus FYM @ $10 \mathrm{t} \mathrm{ha}^{-1}$ was at par with $150 \%$ NPK through fertilizer. Kaushik and Sharma (1997) reported that the grain yield of wheat increased significantly with $8 \mathrm{~kg} \mathrm{~N}$ and $20 \mathrm{~kg} \mathrm{~S}$ per ha application. Santhy et al. (1998) conducted an experiment on the finger millet-maize-cowpea rotation. The data on yield showed that deletion of $\mathrm{K}$ from the fertilizer schedule did not have any deleterious effect on yields. $\mathrm{N}$ application alone reduced the yield of crops remarkably. Application of FYM along with NPK increased the crop yields. 
Tiwari et al. (1998) observed that the incorporation of groundnut haulm @ $7.5 \mathrm{t} \mathrm{ha}^{-1}$ significantly increased the grain and straw yield of wheat both at 50 and $100 \mathrm{~kg}$ levels of N application. Sharma et al. (2000) observed that application of additional dose of N @ $200 \mathrm{~kg} \mathrm{ha}^{-1}$ gave significantly higher grain yield of rice and wheat during all the years of the study than application of the same amount of $\mathrm{N}$ through traditional methods.

Singh et al. (2000) conducted a field experiment for three years on Vertisol under rainfed condition to evaluate the effect of crop rotation viz. cotton-jowar-arhar and found that application of FYM improved the yield of Jowar, cotton and arhar by 33.8, 20.4 and 16.6 per cent over NPK alone. Ravankar et al. (2004) observed that significant positive correlation with the grain yield of sorghum and wheat in long term fertilizer experiment. They also noticed that the soil chemical and biological parameters contributes greatly in the crop yield under sorghum wheat cropping sequence.

Selvi et al. (2004) observed that the indirect effect of the bacterial population in FYM along with inorganic fertilizer treatment reflected in higher yields. Yadvinder Singh et al. (2004) reported that the FYM application to the rice showed significant residual effects in the following wheat crop and produced higher wheat yields than all other treatments. Subehia et al. (2005) reported that addition of lime or FYM along with recommended dose of fertilizer, significantly improved the soil productivity. Further they noticed that both these treatments maintained better nutrient availability and sustained higher grain yields.

Verma et al. (2005) reported that application of $100 \%$ NPK $\left(90,30\right.$ and $\left.15 \mathrm{~kg} \mathrm{ha}^{-1}\right)+$ FYM $\left(10 \mathrm{t} \mathrm{ha}^{-1}\right)$ and $150 \%$ of recommended NPK produced 3.40 to $3.42 \mathrm{t} \mathrm{ha}^{-1}$ maize and 4.05 to $4.08 \mathrm{t} \mathrm{ha}^{-1}$ of wheat.

Considering the importance of soil fertility to improve productivity the study on long term fertilization occupies major role in integrated nutrient management. The agricultural scenario of India was completely changed due to modern intensive agriculture with high doses of fertilizers, insecticides and high yielding fertilizer responsive varieties of crops. Long term fertilizer experiments can be used for monitoring the changes in soil fertility and crop productivity.

\section{Conflict of interest statement}

Authors declare that they have no conflict of interest.

\section{References}

Badanur, U. P., C. M. Poleshi and Balchandra, 1990. Effect of organic matter on crop yields and physico-chemical properties of Vertisols. J. Ind. Soc. Soil Sci. 38, 426-429.

Barik, A.K., Goswami, a., 2003. Efficacy of biofertilizers with $\mathrm{N}$ levels, on growth, productivity and economics in wheat (Triticum aestivum). Ind. J. Agron. 48(2), 100-102.

Bharadwaj, V., Bansal, S.K., aheshwari, S.C., Omanwar, P.K., 1994. Long term effect of continuous rotational cropping and fertilization on crop yield and soil properties changes in the fraction of N, P \& K of the soil. J. Ind. Soc. Soil Sci. 42(3), 392-397.

Bhosekar, V.V., Raikhedkar, S.V., 1990. Effect of levels of N and FYM on yield and yield attributing characters of CSH-6 sorghum. J. Maharashtra Agric. Univ. 15(2), 251252.

Chander, G., Verma, T.S., Sharma, S., 2007. Influence of Boron and FYM on available $\mathrm{B}$ and exchangeable $\mathrm{Ca}$ and their removal by cauliflower in the Boron deficient soils of Himachal Pradesh. J. Ind. Soc. Soil Sci. 55(1), 62-66 .

Dhillon, K.S., Dhillon, S.K., 1991. Effect of crop residues and $\mathrm{P}$ levels on yield of groundnut and wheat grain in a rotation. J. Ind. Soc. Soil Sci. 39, 104-108.

Dhonde, P.W., 1985. Response of kharif sorghum to fertilizers in marathwada region. Sorghum Newslett. 28, 29.

Dixit, K.G., Gupta, B.R., 2000. Effect of FYM, chemical and biofertilizers on yield \& quality of rice and soil properties. J. Ind. Soc. Soil Sci. 48(4), 773-780.

Dudhat, M.S., Malavir, D. D., Mathukia, R.K., Khanpara, V. P., 1997. Effect of nutrient management through organic and inorganic sources on growth, yield, quality and nutrient uptake by wheat. Ind. J. Agron. 42(3), 455-458.

Gupta, M.L., Jain, K.K., Sharma, O.L., Yadav, N.S., 1986. Response of sorghum cultivars to $\mathrm{N}$ under dry farming conditions. J. Dry Farm. 13(10), 566-569.

Hazara, J. N., Nandi, P.K., Mandal, S.K., Debnath, N.C., 1980. Effect of incorporation of undecomposed farm waste on the crop yield. Ind. J. Agric. Chem. 15, 149-152.

Indulkar, B.S., More, S.D., 1985. Interactive effect of nature of salinity and nitrogen on growth and nutrient composition of sorghum. J. Ind. Soc. Soil Sci. 33(3), 641-645.

Kaushik, J., Sharma, H.S., 1997. Effect of N and S levels and uptake of $\mathrm{N}$ in wheat. Ann. Biol. Ludhiana. 3(1), 85-86.

Kulkarni, K.R., Shirwal, A.S., Kulkarni, M.V., 1983. Economy of fertilizers through use of FYM in rice-rice cropping system. Fert. News. 28(3), 291.

Kumar, D., Singh, R., 1984. Effect of FYM on N use efficiency in maize-wheat sequence under rain fed conditions. Bull. Ind. Soc. Soil Sci. 13, 318-325.

Kundu, S., Barman, K.K., Biswas, A.K., Singh, M., 2000. Effect of gypsum application on fate of applied $\mathrm{N}$ and soil $\mathrm{N}$ uptake by wheat in a Typic Haplusterts. J. Ind. Soc. Soil Sci. 48(3), 627-629.

Mali, C.V., Chavhan, M.H., Shaikh, A.R., 1997. Influence of different sources of zinc on yield and nutrient content of crop in sorghum-wheat cropping sequence. J. Soils 
Crops. 3(1), 14-17.

Mandal, B.C., Roy, 1984. Changes in soil N due to continuous cropping and manuring. Bull. J. Ind. Soc. Soil Sci. 13, 250-254

More, S.D., Ghonshikar, C.P., 1984. N use efficiency and its soil balance as influenced by sorghum-wheat and green gram-wheat cropping sequence. Bull. J. Ind. Soc. Soil Sci. 13, 346-350.

Naphade, K.T., Deshmukh, V.N., Rewatkar, S.S., Solanke, B.V., 1993. Grain yield and nutrient uptake by irrigated wheat grown on Vertisol under various nutrient levels. J. Ind. Soc. Soil Sci. 41(2), 370-371.

Naphade, K.T., Deshmukh, V.N., Rewatkar, S.S., Solanke, B.V., 1995. Utilization of nutrients by sorghum-wheat cropping sequence on Vertisol under varying nutrient management. J. Maharashtra Agric. Univ. 20(3), 355-357.

Nazikar, R.B., Adsule, R.N., 2004. Effect of N fertilization on FYM combination on nutrient content and uptake of dry matter of wheat. J. Maharashtra Agric. Univ. 29(3), 339340.

Pandey, P.B., Thakur, S.S., Singh, S.J., MIshra, S.S., 2000. Effect of fertilizer management on growth and yield of wheat. J. Soil Crop. 14(2), 275-282.

Pathak, S.K., Singh, S.B., Zha, R.N., Sharma, R.P., 2005. Effect of nutrient management on nutrient uptake and change in soil fertility in maize- wheat cropping system. Ind. J. Agron. 51(4), 225-226.

Patil, N.D., Patil, R.P., Adsule, R.N., 1984. Influence of $\mathrm{N}$ on yield and quality of sorghum. J. Maharashtra Agric. Univ. 9(2), 172-178.

Raghuvanshi, R.K.S., Umat, R., 1994. Integrated nutrient management in sorghum-wheat cropping system. Ind. J. Agron. 39(2), 193-197.

Randhava, P.S., Arora, C.L., 2000. Phosphorus-sulphur interaction effects on dry matter yield and nutrient uptake by wheat. J. Ind. Soc. Soil Sci. 48(3), 536-540.

Ravankar, H.N., Singh, M.V., Sarap, P.A., 2004. Long term effect of fertilizer application and cropping on the sustenance of soil quality and productivity under sorghumwheat sequence in Vertisol. NATP-RRPS 19. Dr. P. D.K.V. Akola and IISS (ICAR), Bhopal. 12p.

Rawat, K., Naphade, T., Puranik, R.B., Patil, R.T., 2000. Refinement of agro-techniques for improving the productivity of wheat (Triticum aestiuam) under ricewheat agro-ecosystem. Ind. J. Agron. 45(4), 636-640.

Reddy, K.S., Raqueeba, M., 2000. Sulphur imbalanced fertilization in red soils of Tirupati in Andhra Pradesh: in work shop on sulphur imbalanced fertilization (Eds.: Sarkar, M.C., Biswas, B.C., Das, S.) JSI/FAI/IFA Workshop, New Delhi, India. pp.119-122.

Sahrawat, K.L., Rego, T.J., Rahman, M.H., Rao, L.K., 1998. Phosphorus response effect on macro and micro nutrient removal by sorghum under rain fed cropping on a Vertisol. J. Ind. Soc. Soil Sci. 46(1), 58-60.

Santhy, P., Jayasreeshankar, P., Mathuvel, P., Selvi, D., 1998. Long term fertilizer experiment status of $\mathrm{N}, \mathrm{P}$ and $\mathrm{K}$ fractions in soil. J. Ind. Soc. Soil Sci. 46(3), 395-398.
Selvi, D., Santhy, P., Dhakshinamoorthy, M., Maheshwari, M., 2004. Microbial population and biomass in rhizosphere as influenced by continuous intensive cultivation and fertilization in Inceptisol. J. Ind. Soc. Soil Sci. 52(3), 254-257.

Sharma, M.P., Bali, S.V., Gupta, D.K., 2000. Crop yield and properties of Inceptisol as influenced by residue management under rice-wheat cropping sequence. J. Ind. Soc. Soil Sci. 48(3), 506-509.

Singh, G., Singh, O.P., Singh, R.G., Mehata, R.K., Kumar, V., Singh, R.P., 2006. Effect of INM on yield and nutrient uptake of Rice-wheat cropping system of low land of eastern U.P. Ind. J. Agron. 51(2), 85-88.

Singh, J., Venugopalan, M.V., Mannikar, N.D., 2000. Soil fertility and crop productivity changes due to cotton based cropping systems under rain fed conditions. J. Ind. Soc. Soil Sci. 48(2), 282-287.

Srinivasrao, C., Subbarao, A., 1999. Impact of FYM and P application on soil $\mathrm{K}$ status and $\mathrm{K}$ uptake in a Vertisol under soybean-wheat system. J. Ind. Soc. Soil Sci. 47 (1), 176-178.

Subbarao, A., Babrekar, A.G., Gosh, A.B., 1982. Total N and $P$ balance sheet in a Typic Ustochrept soil under intensive cropping and fertilizer use. Plant Soil. 68, 125-129.

Subehia, S.K., Verma, S., Sharma, S.P., 2005. Effect of long term use of chemical fertilizer with and without organics on farms of soil acidity, phosphorus adsorption and crop yield in anacid soil. J. Ind. Soc. Soil Sci. 53(3), 308-313.

Tiwari, K.N., Pathak, A.N., Hari Ram, 1980. Green manuring in combination with fertilizer $\mathrm{N}$ on rice on double cropping system in an alluvial soil. J. Ind. Soc. Soil Sci. 28(2), 162-169.

Tiwari, V.N., Lehri, L.K., Tiwari, K.N., Singh, H., 1998. Effect of incorporation of groundnut plant residues on wheat yield, nutrient uptake and soil productivity. J. Ind. Soc. Soil Sci. 46(1), 43-47.

Tyagi, V.V., Bhardwaj, V., 1994. Effect of continuous cropping and fertilization on the status of available $\mathrm{N}, \mathrm{P}$ and K in Mollisol. J. Pot. Res. 10(4), 384-391.

Vageesh, T.S., Hosmani, M.M., Sharma, K.M.S., 1987. Changes in soil fertility and crop productivity under long term fertilizer use in jowar-wheat sequence. Curr. Res. 16, 138-140.

Vats, M.R., Sehgal, D.K., Mehta, D.K., 2001. Integrated effect of organic manuring on yield sustainability in long term fertilizer experiment. Indian J. Agric. Res. 35(1), 19-24.

Verma, P.H., Epalia, V., Kanthaliya, P.C., 2005. Effect of continuous cropping fertilization on crop yield and nutrient status of a Typic Haplusterts. J. Ind. Soc. Soil Sci. 53(3), 365-368.

Walia, R.S., Singh, R., Yadvinder Singh, 1980. Growth and nutrient uptake behavior wheat as influenced by $\mathrm{N}$ fertilization. J. Ind. Soc. Soil Sci. 28(1), 91-97.

Yaduvanshi, N.P.S., Swarup, A., 2006. Effect of long term fertilization and manuring on $\mathrm{K}$ balance and non exchangeable K released in a reclaimed sodic soil. J. Ind. Soc. Soil Sci. 54(2), 203-207. 
Yadvinder Singh, Singh, B., Ladha, J.K., Khind, C.S., Gupta, R.K., Meelu, O.P., Pasuquin, E., 2004. Long term effects of organic inputs on yield and soil fertility in the ricewheat rotation. Soil Sci. Am. J. 68, 845-853.

Zade, K.B., 1991. Studies on the effect of graded levels of fertilizers on soil properties, uptake of nutrients and yield in Jowar-wheat crop rotation in Vertisol Ph.D (Agri.) Thesis submitted to Dr. P.D.K.V. Akola.
Zbiec, I.I., Marczyk, K., Gurgul, E., Tryakowska, E., Kaszanska, E., 1999. Response of spring wheat cultivar to irrigation and mineral fertilization part III activity of some physiological processes, chemical composition and technological properties of grain. Folio Universities Agriculture. Stetinensis Agricultura. 73, 105-112.

\section{How to cite this article:}

Puli, M. R., Katkhar, R. N., Mitnala, J., Rao, B. R., 2016. Effect of long term fertilization on content and uptake of macro nutrients in sorghum-wheat cropping sequence - A review. Int. J. Curr. Res. Biosci. Plant Biol. 3(6), 105-110. doi: http://dx.doi.org/10.20546/ijcrbp.2016.306.013 